Јелена Гинић

Универзитет у Београду

Филолошки факултет
UDC 371.3::811.161.1

DOI https://doi.org/10.18485/fid.2018.8.ch6

\title{
НАСТАВА РУСКОГ ЈЕЗИКА У ОСНОВНОЈ ШКОЛИ: АКТУЕЛНО СТАњЕ И ПЕРСПЕКТИВА
}

\section{Сажетак}

У раду се осврћемо на наставу руског језика као другог страног језика у основним школама данас, узевши у обзир и њене почетке. Руски језик као други страни у основној школи учи 20\% ученика, док руски као први страни учи свега 1\% ученика. Указујемо на факторе који су важни за стабилност руског језика: уџбеничка литертаура, такмичења, стручна усавршавања, као и на могућности које пружа знање руског језика - бесплатно студирање у Русији, коришћење интернет-ресурса, рад у руским фирмама. Коначно, указујемо на чињеницу да би учење руског језика требало да буде заступљено у већој мери, с обзиром на могућности које знање овог језика пружа.

Кључне речи: руски језик, први/други страни језик, уџбеници, такмичења, билингвална настава,стручно усавршавање, стипендије, руске фирме, интернет-ресурси, међународна сарадња.

\section{Кратак осврт на историјат школског учења руског језика у Србији}

Руски језик у школском систему Србије присутан је од 1902. године (Кончаревић 2004: 31), када је ушао у гимназијску наставу (први разред гимназије по узрасту је одговарао данашњем петом разреду основне школе). Између два светска рата учење руског језика било је маргинализовано (Кончаревић 2004: 31). У првим годинама после Другог светског рата руски језик је у гимназијској настави (учио се од првог разреда гимназије $\left.{ }^{1}\right)$ био обавезан предмет. Могућност учења

1 Тадашњи први разред гимназије еквивалентан је данашњем петом разреду основне школе. 
руског језика већ је 1949/50. године била укинута, после неповољних политичких прилика (Станковић 2008:32). Неповољне прилике по учење руског језика (1953. године $1 \%$ ученика учи руски језик (Кончаревић 2004:32)) трају све до шездесетих година ХХ века, када долази до унапређења сарадње Југославије са Совјетским Савезом, као и до сјајних научних и техничких достигнућа Совјетског Савеза, која су била планетарно позната. Почетком шездесетих година, учење руског језика добија подршку савезне и републичке власти, које су конкретизоване двама документима: Правилником о сировођењу йланова и ироірама школа у йойлеgу насйаве сиираних језика, као и Уйуйсиивом за реализацију датог Правилника, оба из 1961. године: „Потребе заједнице <..> налажу да се у школама задржи могућност учења четири језика који су се до сада учили, и то: руски, енглески, немачки и француски, али да се приоритет да руском и енглеском језику" (у Станковић 2008: 43). Од овог тренутка почиње нагла експанзија учења руског језика, који 1964. године у основним школама Србије учи 54,9\% ученика (Станковић 2008: 44). До седамдесетих година заступљеност руског језика у школама Србије била је око 60\%. Овде бисмо истакли да Славистичко друштво Србије, које се залагало за враћање руског језика у школе Србије, није желело овакав развој ситуације: учење руског језика науштрб свих осталих. Проф. Станковић преноси речи тадашњег председника Друштва, Александра Белића: „треба руски коначно поставити у равноправан положај с осталим страним језицима. <.. >дискриминација према било ком страном језику штетна [je] за наш просветни развитак" (Станковић 2008: 45). Током шездесетих година и почетком седамдесетих долази до померања заступљености руског језика: он се потискује из градских средина у корист енглеског језика, а постојанији је у сеоским школама (Станковић 2008: 73). Без обзира на овакву социолингвистичку политику (руски језик постаје „непрестижан”, учи се у мањим, сиромашнијим срединама), њега школске 1977/78. године учи 51\% ученика, док енглески језик учи $22 \%$, француски 20\% и немачки $7 \%$ ученика. Наставу изводи укупно 1427 наставника и професора у основним и средњим школама (Станковић 2008: 74). Данас, по подацима Славистичког друштва Србије, на списку је око 500 професора и наставника руског језика (притом немају сви пун фонд часова). Њихов број се, у односу на осамдесе- 
те године, смањио три пута. Деведесетих година наставља се тренд смањивања интересовања за учење руског језика. Совјетски Савез се распада, а Русија, његова наследница, економски и политички је исцрпљена и њен политички и културни утицај готово нестаје. С друге стране, Југославија се распада, политичке и економске прилике су такође, најблаже речено, неповољне, и у таквим тренуцима питања образовања потиснута су у други план. У оваквим околностима дистрибуција страних језика препуштена је случају. Ни данас не постоји јасна државна стратегија учења појединих страних језика која би била у складу с економским, културним, научним, стручним потребама и потреба тржишта рада. Деведесете и двехиљадите године су врло неповољне за статус руског језика, нарочито у основним школама Србије. Он се истискује из школа без институционалне подршке, уз притиске директора који удовољавају притисцима родитеља, те руски, још једном бива потиснут из остатка централних градских школа на периферију, и очуван, донекле, у сеоским срединама и на ободима градова.

\section{Руски језик као други страни језик данас}

2000. године започет је велики пројекат реформе образовања. Учење првог страног језика спуштено је у први разред основне школе (почињао је од петог разреда претходно), док је почетак учења другог страног језика из трећег разреда основне школе премештен у пети разред. Руски, као и сви остали језици осим енглеског, овим су аутоматски добили статус другог страног језика. Руски се као први страни језик данас учи веома мало: према подацима објављеним у дневном листу Новосии, у првом разреду основне школе од генерације која броји нешто преко 60.000 ученика, руски као први страни учи свега 259 деце (Новости, 18.4.2016), док 711 ученика учи немачки као први, а 986 деце француски.Уколико узмемо у обзир чињеницу да руски језик као први страни језик у осмом разреду учи 711 ученика $^{2}($ Новостии, 18.4.2016), можемо закључити да је број ученика који уче руски као први језик три пута мањи у првом разреду у односу на

2 Немачки учи 719 ученика, а француски 1.108 према истом извору. 
осми, док француски и немачки језик не бележе овакве падове. Узроке овога видимо у поменутој „непрестижности” учења руског језика, предрасуда да руски језик уче слабији ученици, о чему сведочи и рад Биљане Марић која је овим поводом спроводила анкету међу наставницима руског језика на фејзбук групи (Марич 2015: 29)³.

У великој већини школа руски језик је други страни језик, учи се од 5. разреда. Какво је његово место у односу на остале језике? Подаци одбјављени у дневном листу Полиииика (Полиииика, 12.10. 2015.) сведоче о укупном броју ученика који уче страни језик као први и други страни језик. Целокупна популација ученика од 1. до 8. разреда броји нешто мање од 600.000 ученика; од тога 459.357, односно 76,5\% ученика учи енглески језик, 116.857, односно 19,5\% учи немачки језик, 81.021 (око 13,5\%) учи француски језик, док руски учи 55.873 ученика (приближно 9,3\%), док најмањи број ученика учи италијански језик: 12.597 (2,1\%) и шпански језик: 5.950 ученика (око 1\%). Ово је за око 8.000 мање у односу на 2012. годину: у складу с подацима Министарства просвете, 2012. године руски језик је учило око 63.000 ученика, односно, сваки десети ученик (Маркович 2014: 151). Дакле, 2016. године се, у односу на 2012. бележи смањење учења руског језика за 1,5\% у односу на 2012. годину (смањење делимично може бити узроковано и смањењем укупног броја ученика у општој популацији).

Подаци Министарства просвете који су добијени после опредељивања ученика основних школа за одређени уџбенички комплет (Министиарсӣво, 2016), дају нам прецизне податке о броју ученика који уче стране језике, било као прве или друге стране. Будући да је тежиште нашег излагања на руском језику као другом страном, концентрисаћемо се на ове резултате: у петом разреду руски језик учи као други страни (обавезно-изборни предмет) 14.357 ученика. Немачки, рецимо, учи

3 Дате предрасуде, с једне стране, имају узрок у чињеници да су руски и српски сродни језици, да је руски, према датом стереотипу, мало измењени српски језик (више о овоме у Марић 2014: 29). С друге стране, руски језик се у нашој средини и даље поистовећује са Совјетским Савезом,сиромаштвом, репресијама режима. Ову предрасуду треба разбити: савремена Русија је модерна земља која се својом естетиком разликује од западног света, али по свему другом, савременом начину живота, својој мултикултуралности, начину пословања, веома личи на западноевропске земље, много више од савремене Србије. 
32.827 ученика, француски 19.108, италијански 3.264, шпански - 1.385 ученика. Један број ученика 5. разреда учи и енглески као обавезни изборни предмет - 2.868. Сабравши дате цифре, добијамо број ученика генерације: 73.809 ученика. Судећи по датим чињеницама, руски језик учи око 19\% ученика генерације петог разреда као други страни језик. У шестом разреду, од генерације која броји 74.079 ученика, руски као обавезни изборни предмет учи 14.610 ученика, односно готово 20\% ученика генерације будућег шестог разреда. Будућа генерација седмака броји 70.412 ученика. 14.309 ученика руски учи као други страни језик, што чини његову заступљеност у нешто више од 20\% опште ученичке популације будуће генерације седмака. Генерација будућих осмака има 69.399 ученика, а руски језик као други страни учи 14.050 ученика, такође нешто више од 20\%. Језик који је назаступљенији као други страни језик убедљиво је немачки, следи француски, затим руски, те италијански и, коначно, шпански.

Заступљеност руског језика као другог страног у школама са нешто више или мање од 20\% је сасвим задовољавајућа. Није задовољавајућа његова застуљеност као првог страног језика у школама, у којима, у Србији укупно, руски као први страни језик учи тек десетак до двадесет одељења годишње (у зависности од конкретног разреда). Сматрамо да постоје потребе за његовим већим учењем као првог страног, на нивоу од око 10\% због потреба на које ћемо указати даље у раду.

\section{Фактори стабилности руског језика у Србији}

\section{Уџбеници, граматике, речници}

За руски језик као обавезни предмет по избору постоје три уџбеничка комплета која имају дозволу Министарства просвете за наредни четворогодишњи период: уџбенички комплет Орбий (Завод за уџбенике), уџбенички комплет Диалої (DataStatus), и уџбенички комплет Конечно! (Klett). Сва три уџбеничка комплета добила су одобрење Министарства просвете и биће у употреби у наредне четири године, када се иде у нови круг акредитације уџбеника. Могућност избора уџбеника разних издавача и различитих методичких приступа за исти предмет је 
веома важна и позитивна ствар: самом предмету више од једног уџбеника даје на значају, наставници могу да се определе за један од три уџбеника и нису у подређеном положају у односу на наставнике других страних језика, којима се нуде уџбениџи већег броја издавача. Лошија је ситуација за руски језик као први страни, за који постоји само један уџбенички комплет (Роgничок, Завод за уџбенике).

За основну школу постоји дидактичка граматика Богољуба Станковића и Љубице Несторов, као и двојезични (руско-српски и српско-руски) речник Богољуба Станковића. Осећа се потреба за једном педагошком граматиком, какву има француски језик.

\section{Билингвална настава}

Сматрамо да је билингвална настава може бити важан фактор стабилности језика. Пројекат билингвалне руско-српске наставеу ОШ „Олга Петров” у Падинској Скели трајао је свега неколико година (од 2008. године, када је школа на челу с директором Мирком Милојевићем, русистом, ушла у пројекат билингвалних школа, па до 2012. године, више о самом почетку пројекта видети у Милоевич 2009). Данас билингвална настава постоји само у једној основној школи, ОШ „Јован Поповић” у Новом Саду, и то, за сада, у нижим разредима: школске 2014/15. године отпочела је билингвална настава за 37 деце првог и другог разреда (Нови Cag 8.9.2014). Подршку пројекту дала је Амбасада Руске Федерације и компанија НИС Гасиромњефй. Руско-српска билингвална настава постоји и у две гимназије: Алексиначкој гимназији, пројекат је започео исте, 2014. године, компанија НИС опремила је рачунарски кабинет и у билингвално одељење уписана су 24 ученика (НИС, 9.10.2014). Школске 2015/16. билингвална настав започела је у Гимназији „Јован Јовановић Змај” у Новом Саду. Пројекти билингвалних школа у већој мери и из више области приближавају руски језик и културу и требало би настојати да се оваква настава покрене у још неколико основних школа.

\section{Такмичења из руског језика}

Поред државног такмичења које сваке године организује Друшииво за стиране језике, већ четврту годину заредом одржава се НИСова олим- 
йијаgа из рускої језика за ученике Србије, Црне Горе и Рейублике Срӣске, у којој се могу такмичити ученици од седмог разреда основне школе до четвртог средње школе, као и у специјалној категорији. Такмичење је ушло у календар школских такмичења. Циљ овог такмичења јесте популаризација руског језика и сваке године је такмичење све масовније. Прве године учествовало је окнешто мање од 500 ученика у првом кругу, нешто мање од 100 ученика у финалном кругу, да би ове године је у првом кругу (који се одвија у школама) учествовало преко 1.200 ученика. У финале се пласирало око 170 ученика. Идеја и реализација потекла је од професора руског језика Гимназије Јован Јовановић 3мај и координатора Рускоі изенйра у Новом Саду, Ненада Спасића. У организацији учествује Славистиичко ярушитво Србије, Руски иченйар у Новом Саду, уз финансијску и просторну подршку НИС Гасиромњефйа. Од наредне школске године у организацију Олимпијаде укључиће се и Универзитет Лобачевски из Нижњег Новгорода.

\section{Стручна усавршавања из руског језика}

Претходних неколико година у Каталогу стручних усавршавања ЗУОВ-абио је један, највише два семинара за стручно усавршавање наставника руског језика. У наредном двогодишњем периоду (школска 2016/17-2018/19), од 31 програма стручног усавршавања за ужу стручну област „страни језик”, за руски језик акредитована су четири програма стручног усавршавања: (један Славистичког друштва Сpбије, под редним бројем 743, један Дайа Дияакйе, под редним бројем 739, један Центра за усавршавање наставника Филозофскоі факулиее$\bar{u} a$ у Новом Саду, под редним бројем 749, као и програм ОШ Драїојло Дуguћ, под редним бројем 753) (ЗУОВ, 2016). Дуго је у програмима стручног усавршавања Зимска школа (традиционални назив стручног усавршања које организује Славистиччко ярушииво Србије) био једини семинар у Каталогу и ово повећање на 4 уже-стручна семинара за наставнике руског језика је један помак који ће позитивно утицати на будући статус руског језика у Србији. 


\section{Могућности које пружа учење руског језика}

\section{Стипендије Руске Федерације}

Руска Федерација 2016. даје укупно 15.000 стипендија за бесплатно студирање на 400 руских универзитета. На ова места могу конкурисати грађани 198 земаља света. Прошле школске године 138 грађана Србије добило је стипендије за студије у Руској Федерацији, од медицине до техничких наука, укључујући и нуклеарну физику. Русисти, лингвисти и филолози су посебно издвојени (Руска реч, 4.3.2016). Ове године квоте за Србију су износиле 85 стипендија, а пријављених кандидата, по речима Татјане Горшкове, сараднице Амбасаде Руске Федерације за питања образовања, било је 336. Због великог интересовања у последњих неколико година за студирање у Руској Федерацији, руска страна би требало да размотри могућност повећања квота за грађане Србије ${ }^{4}$.

\section{Руски језик на интернету}

Руски језик је други, после енглеског, по популарности на интернету, према подацима из маја 2016. године (истраживање сајта Web Technology Survey). Руски језик на интернету заступљен је са 6,4\% укупног садржаја, испред немачког је (заступљен с 5,5\%) а после енглеског (заступљен са 53,5\%). До предности руског у односу на немачки језик по популарности на инетрнету дошло је 2013. године. (Ленй $а, 21.3 .2013)$.

\section{Руски језик и превођење}

Премаподацима УНЕСКА, енглески, француски, немачки и руски језик су најпревођенији језици на свету (УН,19.04.2012).

\section{Фирме с руским капиталом}

Према резултатима истраживања сајта Poslovi.infostud.com спроведеном на више од 10.000 испитаника, стране компаније су пожељ-

4 Иако су квоте 85, могуће је да ће и ове године, као и прошле школске, бити додељено више од овог броја стипендија грађанима Србије, јер се подаци свих пријављених налазе усистему (региструју се на порталу www.russia. study), тако да сами универзитети могу директно прихватити одређеног кандидата, чак и ако није ушао у ову квоту од 85 студената. 
није за запошљавање од домаћих, а на листи најбоље оцењених страних и домаћих компанија, НИС Гасиромњефй је заузео друго место после Кока-коле, а испред Теленора, Епса, Телекома, Noredeusd.o.o, Мајкрософта, Делта холдинга и Пошта Србије (Danas, 23.5.2016).

\section{Уместо закључка}

Знање руског језика данас може да има много предности уз основно занимање/школовање: почев од служења литературом на руском језику, рускојезичним интернетом који има огромне отворене базе стручне и научне литературе (руске и преводне), преко могућности за бесплатно студирање на великом броју руских универзитета, запошљавања у домаћим фирмама с руским капиталом и запошљавања у Русији.

Због све већих потреба за знањем руског језика код нас и у свету, сматрамо да је руски језик у нашем основном образовању недовољно заступљен, с укупних 9\% (када заједно узмемо учење руског као првог и као другог страног језика). Овај проценат би било пожељно довести до $15 \%$ и то повећавајући проценат школа које руски језик уче као први страни. Другим речима, повећати учење руског науштрб енглеског. Проценат руског као другог страног језика у школама је задовољавајући (20\%).

Руски језик као страни језик у школама нема, суштински (иако формално има), исти положај као остали, западни језици. Ученицима (а неретко и родитељима) треба разбити стереотипе о руском као мање страном и мање престижном језику, а то се може само чињеницама, знањем, упорношћу и љубављу према предмету који се предаје, али и према деци; нису ретки наставници који у овом успевају 5 .

5 Рецимо, у овоме је успела учитељица Марија Петровић Алексић, која ради у ОШ „Драган Лукић“ на Бежанијској Коси (поред Учитељског факултета, она је завршила и Филолошки факултет, Групу за руски језик и књижевност): њени ученици праве изузетне приредбе на руском језику, певају на њему и рецитују, а не могу да га одаберу од петог разреда, јер га нема у понуди. По речима ове учитељице, заинтересовани су и родитељи и деца, а од петог разреда могу бирати француски и немачки, али не и руски. Треба радити на томе да се омогући бирање руског језика од петог разреда у овој школи. 
Руска Феgеращија, Амбасаgа Руске Феgераиије у Београду, фонд Руски мир би могли да помогну разбијању ових стереотипа финансијском и стручном подршком, и то:

- масовнијим позивањем (не једног до троје годишње) наставника руског језика из Србије на стручна усавршавања са посетама руским оштеобразовним и стручним школама, с комплетним финансијским учешћем руске стране;

- масовнијим позивањем ученика из Србије на међународне кампове (попут Московије) с комплетним финансијским учешћем руске стране;

- подршци отварању билингвалних одељења спозивањем наставника различитих предмета у Руску Федерацију, како би се усавршавали се у школама Русије, с комплетним финансијским учешћем руске стране;

- организовањем курсева руског језика у Русији за наставнике који ће изводити билингвалну наставу, с посебним освртом на предмет који предају, с потпуним финансијским учешћем руске стране;

- већим квотама за бесплатно студирање на руским универзитетима;

- организовањем летњих школа руског језика за ученике стручних школа и гимназија с комплетним финансијским учешћем руске стране;

- опремањем кабинета руског језика у школама, опремањем фонетских лабораторија у школама у којима се учи руски језик;

- финансијским и стручним посредовањем у организовању размене наставника руског језика (или других предмета) и ученика ${ }^{6}$.

6 Овакву сарадњу су успоставиле неке основне и средње школе и успешно је, годинама, остварују (ОШ „Иван Горан Ковачић”,ОШ „,20. октобар“, Прва београдска гимназија, Девета београдска гимназија), али је целокупна размена препуштена ентузијазму наставника руског језика (сво администрирање, посредовање, а финансијско учешће ученицима који путују/примају госте, њиховим родитељима и наставницима). 


\section{Референце:}

Кончаревић (2004): Кончаревић, К. Савремена насйава руско̄ језика. Саяржаји, оріанизащија, облици. Београд: Славистичко друштво Србије.

Марич (2015): Марич, Б. Состояние и перспективы изучения русского языка в инославянской среде. In: Альманах Эйноgиалоїи. - №1 (48). 26-34.

Маркович (2014): Маркович, Д. Преподавание русского языка в Сербии, актуальные проблемы в сокращении часов и возможные пути их решения. In: Наука и савремени универзииеей 4. 148-153.

Милоевич (2009): Милоевич, М. Опыт преподавания русского языка в двуязычном обучении. In: Русский язык как инославянский I. $123-126$.

Станковић (2008): Станковић, Б. 60 іооина Славистиичкой gрушӣва Србије.Београд: Славистичко друштво Србије.

\section{Интернет-ресурси}

ЗУОВ (2016): http://katalog2016.zuov.rs/Default.aspx?oblast=30\# kompetencije (приступљено 13.9.2016)

Ленйа, 21.3.2013: https://lenta.ru/news/2013/03/21/strussian/ (приступљено 25.5.2016)

НИС, 9.10.2014: http://www.nis.eu/lat/presscentar/bilingvalna-nastavau-aleksinackoj-gimnaziji (приступљено 11.5.2016)

Нови Cag, 8.9.2014: http://www.novisad.rs/lat/otvorena-bilingvalnaodeljenja-u-os-jovan-popovic (приступљено 11.5.2016)

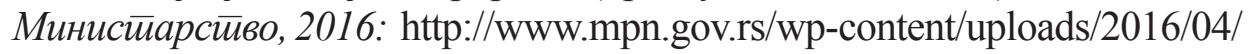
udz_kompleti_STRANI_JEZIK.pdf (приступљено 25.5.2016)

Новости $u$, 18.4.2016: http://www.novosti.rs/vesti/naslovna/drustvo/ aktuelno.290.html:601207-Drugi-strani-jezik-ce-uciti-samo-ko-zeli (приступљено 24. 5. 2016)

Полийика, 12.10. 2015. http://www.politika.rs/scc/clanak/340684/Engleskiu-skolama-gasi-druge-jezike (приступљено 24.5. 2016)

Руска реч, 4.3.2016. http://ruskarec.ru/news/2016/03/04/rusija-poziva15-hiljada-stranih-drzavljana-na-besplatno-studiranje_573159 (приступљено 25.5.2016) 
УH,19.04.2012: http://www.un.org/russian/news/story.asp?NewsID=17340\#. V0Xyr_197Mw (приступљено 25.5.2016)

Danas, 23.5.2016: http://www.danas.rs/dodaci/biznis/_strane_kompanije_ pozeljnije_od_drzavnih_.27.html?news_id=321021(приступљено 23.5.2016)

Web Technology Survey: https://w3techs.com/technologies/overview/content language/all (приступљено 25.5.2016)

\section{Jelena Ginić}

\section{TEACHING RUSSIAN IN ELEMENTARY EDUCATION: CURRENT SITUATION AND FUTURE PERSPECTIVES}

\section{Summary}

Teaching of Russian as a second foreign language in elementary education is discussed in this paper. Russian as a second foreign language in primary schools is studied by $20 \%$ of all pupils, while Russian as a first foreign language is studied by only $1 \%$ of pupils. Herein, I point to the factors contributing to the stability of the presence of Russian: textbooks, competitions, life long teacher education programs, as well as benefits from being able to use the language, such as free education in Russia, use of internet resources (second in volume only to those in English), and the possibility of cooperation with Russian enterprises. I point to the fact that teaching of Russian should be more widespread and that its presence should be elevated from the current $9 \%$ (the percentage of pupils studying Russian either as a first or a second foreign language) to at least $15 \%$, bearing in mind the above cited benefits of linguistic competences in Russian. Furthermore, I identify a series of factors which could be applied in cooperation with Russian partners in order to improve the quality of teaching and raise the interest of pupils for studying Russian: international camps, Russian language courses in Russia for Russian language professionals and non-professionals (teachers of different subjects in bilingual classes) with financial support by potential Russian partners.

Keywords: Russian as a first foreign language, Russian as a second foreign language, elementary education, Serbia. 